\title{
Primary care features in child hospitalization: First-contact access and Longitudinality
}

\author{
Atributos da atenção primária nas internações de crianças: Acesso de primeiro contato e \\ Longitudinalidade
}

Jessica Lima Benevides ${ }^{1}$, Fabiane do Amaral Gubert ${ }^{1}$, Marcela Ariadne Braga Gomes Tomé ${ }^{1}$, Patricia Freire de Vasconcelos ${ }^{2}$, Regina Cláudia Melo Dodt ${ }^{1}$, Sarah Rayssa Cordeiro Sales Pinheiro ${ }^{1}$

\begin{abstract}
Objective: to identify two features of primary health care, namely First-contact access and Longitudinality in hospitalized children. Methods: cross-sectional study carried out in two hospitals with 120 children under five years of age hospitalized due to sensitive conditions of primary health care. Data collection performed using the Primary Care Assessment Tool. Results: the degree of affiliation obtained a better score (approximately 8.0 ), being the only one among all components of the instrument satisfactorily evaluated $(\geq 6.6)$. Longitudinality (>4.0) had a lower score than First-contact access (5.6). According to the parents, the nurse was the professional who had most performed the follow-up in childcare. Conclusion: the results point to weaknesses in services and carergivers' dissatisfaction, evidenced by the poor following to the Primary Health Care principles.
\end{abstract}

Descriptors: Child Care; Primary Health Care; Nursing.

Objetivo: identificar os atributos da atenção primária à saúde Acesso de primeiro contato e Longitudinalidade em crianças hospitalizadas. Métodos: estudo transversal, realizado em dois hospitais, com 120 crianças menores de cinco anos de idade internadas por condições sensíveis à atenção primária em saúde. Coleta de dados realizada utilizando o Primary Care Assessment Tool. Resultados: o grau de afiliação obteve melhor escore (aproximadamente 8,0), sendo o único entre todos os componentes do instrumento avaliado de forma satisfatória $(\geq 6,6)$. A Longitudinalidade $(>4,0)$ apresentou menor escore em comparação ao Acesso de primeiro contato $(5,6)$. Segundo os pais, o enfermeiro foi o profissional que mais realizou o acompanhamento na Puericultura. Conclusão: os resultados apontam fragilidades nos serviços e insatisfação dos cuidadores, evidenciados pela baixa orientação aos princípios da Atenção Primária à Saúde.

Descritores: Cuidado da Criança; Atenção Primaria à Saúde; Enfermagem.

${ }^{1}$ Universidade Federal do Ceará. Fortaleza, CE, Brazil.
${ }^{2}$ Universidade da Integração Internacional da Lusofonia Afro-Brasileira, Redenção, CE, Brazil.

Corresponding author: Jéssica Lima Benevides

Av. Luciano Carneiro, 2585. Bl. C, Apt. 102. Vila União, CEP: 60410-691. Fortaleza, CE, Brazil. E-mail: jessicalbenevides@yahoo.com.br 


\section{Introduction}

In view of the obvious limitation of the hierarchical health system in the country, there has been a current tendency to structure the health care model from the Health Care Network system, which is a new way of organizing the health care system in integrated systems that can meet with effectiveness, efficiency, safety, quality and equity the health conditions of the Brazilian population ${ }^{(1-2)}$.

In Health Care Networks, Primary Health Care plays a prominent role in coordinating and guiding health care, as well as its features, which can be verified through Primary Health Care assessment instruments, such as the Primary Care Assessment Tool (PCA-Tool). In this study, the features First-contact access and Longitudinality were deepened, the former being understood as the accessibility and use of the service to each new problem or episode of a problem; and the latter presupposes the existence of a regular form of care and its use over time. It is understood that these features allow to understand the Health Care Network and how it presents itself at each stage of the life cycle ${ }^{(3)}$.

In childhood, the most prevalent injuries among children aged 0-5 are pneumonia and diarrhea, which continue to be the main causes of death in children ${ }^{(4)}$. These diseases have been associated with low socioeconomic levels and are closely linked to factors such as poor domestic environments, malnutrition and lack of access to basic services ${ }^{(5)}$

In this sense, to evaluate the performance of the network, health indicators identifying features that are difficult to verify are used, such as hospitalizations for primary care-related conditions ${ }^{(6)}$. Thus, high rates of hospitalizations due to primary care-related conditions are associated with deficiencies in the coverage of services or of the features of Primary Health Care and/or the low resolution of the Health Care Network for certain health problems.

In Primary Health Care, one of the duties of nurses is to carry out childcare consultations, assess heal- th conditions and propose care plans for children and their families, as well as evaluate child health care $^{(7)}$.

In this context, the objective of the present study was to identify the primary health care features First-contact access and Longitudinality in hospitalized children.

\section{Methods}

This is a cross-sectional study carried out in two pediatric hospitals, one in secondary care and the other in tertiary care, in a capital city of Northeast Brazil. The population was composed of children between zero and five years old, of both sexes, admitted in the hospitals, with diagnosis of diarrhea, pneumonia or asthma ${ }^{(8)}$.

The sample was composed of 120 children. The calculation of the sample size was performed by using a formula used in cross-sectional studies for finite populations. A 95\% confidence interval and relative sample error of $8 \%$ was set.

A non-probabilistic sampling was performed by convenience (consecutive). The interview took place in a private place, with the main caregiver of the hospitalized child, and the data collection was performed using the Primary Care Assessment Tool-Brazil (PCATool-Brazil), prepared and validated in Brazil ${ }^{(3)}$, which addresses the presence and extent of the essential features and derivatives of Primary Health Care in child health care services and the degree of affiliation of the user with the health service.

The PCATool-Brazil Children version has 55 items. In this study, only the first two features (First-contact access and Longitudinality) were used, which correspond to 28 items. The First-contact access feature is subdivided into three components: Degree of affiliation, Use and Accessibility. To apply the instrument, the primary caregiver was asked which was the favorite type of service for the child's health care.

Data were also collected on the sociodemographic and economic characteristics of the family (age of the child and mother, number of people in the hou- 
sehold, family income, caregiver's education) and on attendance at child care consultations in Primary Health Care.

The instrument responses are of the Likert type, and for each alternative a score is given $(4,3,2$, 1 and 9 , respectively) whose sum is transformed into a score by means of statistical calculations defined in the PCATool manual ${ }^{(3)}$, which, when converted to a scale of 0 to 10 , scores greater or equal to 6.6 are considered satisfactory for primary $\operatorname{care}^{(9)}$.

Data processing and analysis were performed through an online questionnaire using the Google Drive tool and analyzed by the Statistical Package for the Social Sciences program, version 20. To better understand the phenomenon of study, resorted the descriptive analysis of tables and graphs in order to find possible patterns in the collected data, which also facilitated the study summary.

In order to evaluate whether or not there were differences in the means of the sociodemographic variables, we applied the Kruskal-Wallis test, which is a non-parametric test that evaluates if there is a statistically significant difference between the means of the categories of the group of a given phenomenon under study. The groups here are each sociodemographic variable and the categories, the possible response options.

To conclude whether there was significance, the level of $10.0 \%$ was set; this indicates that if the $\mathrm{p}$-value is less than 0.10 , there is difference between the compared means; if it is greater than 0.10 , the categories in the group produce statistically the same average.

The present study was approved by the Research Ethics Committee of the Federal University of Ceará under opinion no $1,292,581$.

\section{Results}

The caregivers' age range varied between 14 and 23 years, of which 46 (38.3\%) were mothers. In relation to schooling, $72(70.0 \%)$ had completed ele- mentary school, 85 (70.8\%) were married or have a stable union, and 70 (58.3\%) were housewives. There was a higher prevalence of families composed of 2 to 4 members, 68 (56.7\%) received social benefit from the federal government, the Bolsa Família program; 75 (62.5\%) had a family income of only one minimum wage; and $62(51.7 \%)$ of the households had 3 to 5 rooms.

When the mean scores of Primary Health Care features were verified, the Longitudinality $(>4.0)$ feature presented lower score than the First-contact access (5.6). When dismembering the First-contact access feature, we have the first three components weighted in the Primary Health Care assessment instrument called Degree of affiliation (A), Use (B) and Accessibility (C). The degree of affiliation obtained a better score (approximately 8.0), being the only one among all components of the instrument satisfactorily evaluated $(\geq 6.6)$. The other features presented scores of approximately 6.0 and 3.0, respectively, as mean scores, according to Table 1.

Table 1 - Mean score of features by means of the metric scale from 0 to 10

\begin{tabular}{lcccc}
\hline Primary Health Care features & $\begin{array}{c}\text { Mini- } \\
\text { mum }\end{array}$ & $\begin{array}{c}\text { Maxi- } \\
\text { mum }\end{array}$ & Mean & $\begin{array}{c}\text { 95\% CI of } \\
\text { Mean }\end{array}$ \\
\hline Affiliation (A) & 0.00 & 10.00 & 7.97 & $(7.42 ; 8.53)$ \\
Use (B) & 0.00 & 10.00 & 5.74 & $(5.18 ; 6.31)$ \\
Acessibility (C) & 0.00 & 8.33 & 3.09 & $(2.7 ; 3.48)$ \\
First-contact access (A, B, C) * & 0.56 & 8.89 & 5.60 & $(5.26 ; 5.94)$ \\
Longitudinality (D)* & 0.24 & 10.00 & 4.39 & $(4.02 ; 4.77)$ \\
Overall mean & 0.83 & 8.75 & 5.30 & $(4.99 ; 5.61)$ \\
\hline *Wilcoxon's test, p <0.001; IC = Confidence Interval & &
\end{tabular}

Table 2 shows that when associating the features to the variable age (of mothers/caregivers) there is an association between Longitudinality (D) and the age of the mother/caregiver ( $p=0.077$ ). In terms of schooling, there was an association between the Degree of affiliation component (A) of the First-contact access feature and secondary education $(\mathrm{p}=0.023)$ and between the Longitudinality feature (D) and elementary education $(\mathrm{p}=0.065)$. 
There was also association with the Use component (B) of the First-contact access feature and the number of residents in the household, as well as between the Accessibility component $(\mathrm{C})$ and the receiving of the Bolsa Família program.

Table 2 - Comparison of components A (Degree of affiliation), B (Use), C (Accessibility) and D (Longitudinality) and each sociodemographic variable of the mother/caregiver

\begin{tabular}{|c|c|c|c|c|}
\hline Indicator/Category & $\mathbf{A}$ & B & C & D \\
\hline \multicolumn{5}{|l|}{ Caregiver's age } \\
\hline $14-23$ & 7.97 & 5.63 & 3.20 & 4.47 \\
\hline $24-28$ & 7.92 & 6.22 & 3.42 & 5.03 \\
\hline $29+$ & 8.02 & 5.50 & 2.72 & 3.83 \\
\hline P-value & 0.930 & 0.466 & 0.331 & 0.077 \\
\hline \multicolumn{5}{|l|}{ Schooling } \\
\hline Elementary & 7.50 & 6.03 & 3.29 & 4.73 \\
\hline Secondary & 8.68 & 5.30 & 2.80 & 3.90 \\
\hline P-value & 0.023 & 0.139 & 0.218 & 0.065 \\
\hline \multicolumn{5}{|l|}{ Marital status } \\
\hline Married/Stable Union & 7.96 & 5.76 & 3.01 & 4.47 \\
\hline Single/Divorced/Widowed & 8.00 & 5.68 & 3.29 & 4.22 \\
\hline P-value & 0.849 & 0.937 & 0.529 & 0.358 \\
\hline \multicolumn{5}{|l|}{ Occupation } \\
\hline Housewife & 7.71 & 5.75 & 3.10 & 4.46 \\
\hline Formal or informal employment & 8.50 & 5.86 & 2.89 & 4.14 \\
\hline Student & 7.92 & 4.86 & 3.40 & 4.43 \\
\hline P-value & 0.412 & 0.593 & 0.615 & 0.868 \\
\hline \multicolumn{5}{|l|}{ Bolsa família program } \\
\hline No & 7.93 & 5.26 & 2.62 & 4.09 \\
\hline Yes & 8.00 & 6.03 & 3.38 & 4.58 \\
\hline P-value & 0.789 & 0.193 & 0.067 & 0.304 \\
\hline \multicolumn{5}{|l|}{ Family income (minimum wage)* } \\
\hline$<1$ & 8.21 & 6.45 & 2.67 & 4.40 \\
\hline 1 & 8.39 & 5.93 & 3.28 & 4.57 \\
\hline At least two & 6.98 & 4.79 & 3.07 & 4.05 \\
\hline P-value & 0.135 & 0.106 & 0.538 & 0.558 \\
\hline
\end{tabular}

With regard to sociodemographic data, we observed an association between the variable age (child) and Longitudinality (D) ( $p=0.043)$. Regarding exclusive breastfeeding, there was an association between the Longitudinality feature (D) and breastfeeding until two and four months ( $p=0.072)$; the Use component (B) of the First-contact access feature and the frequency in childcare consultations $(\mathrm{p}=0.020)$, according to Table 3.

Table 3 - Comparison of components A (Degree of affiliation), B (Use), C (Accessibility) and D (Longitudinality) and variables related to children's health

\begin{tabular}{lcccc}
\hline Indicator/Category & $\mathbf{A}$ & $\mathbf{B}$ & $\mathbf{C}$ & $\mathbf{D}$ \\
\hline Child's age (months) & & & & \\
3-13 & 7.95 & 5.98 & 2.89 & 4.42 \\
14-25 & 7.97 & 6.04 & 3.33 & 4.97 \\
26+ & 8.00 & 5.19 & 3.04 & 3.78 \\
P-value & 0.909 & 0.408 & 0.587 & 0.043 \\
Had exclusively breastfed (months) & & & & \\
Up to 1 & 6.67 & 5.82 & 2.75 & 3.56 \\
2 to 4 & 8.38 & 6.30 & 3.23 & 4.82 \\
Up to 6 & 8.17 & 5.35 & 3.12 & 4.41 \\
P-value & 0.186 & 0.328 & 0.676 & 0.072 \\
Attends Childcare & & & & \\
No & 7.47 & 5.09 & 2.79 & 4.17 \\
Yes & 8.51 & 6.44 & 3.42 & 4.63 \\
P-value & 0.150 & 0.020 & 0.118 & 0.270 \\
Had attended childcare until what age & & & & \\
(months)? & & & & \\
0 to 6 & 7.64 & 5.09 & 2.73 & 3.53 \\
7 to 12 & 7.50 & 5.63 & 2.81 & 4.18 \\
13 to 36 & 8.48 & 4.04 & 2.12 & 4.46 \\
P-value & 0.739 & 0.329 & 0.552 & 0.243 \\
Who carried out the consultations & & & & \\
Only the nurse & 7.64 & 5.93 & 3.14 & 4.54 \\
Nurse and physician & 8.57 & 5.78 & 3.08 & 4.54 \\
Only the physician & 8.55 & 5.65 & 3.04 & 3.69 \\
Not applicable & 6.67 & 5.16 & 3.06 & 4.68 \\
P-value & 0.121 & 0.961 & 0.926 & 0.209 \\
Diagnosis of current hospitalization & & & & \\
Asthma/Pneumonia & 7.62 & 5.39 & 3.15 & 4.32 \\
Diarrhea & 8.85 & 6.48 & 2.78 & 4.66 \\
P-value & 0.116 & 0.119 & 0.438 & 0.354 \\
\hline & & & & \\
\hline
\end{tabular}

\section{Discussion}

The major limitation of the study was the considerable loss of eligible candidates for not performing follow-up in Primary Health Care Units. However, these results are relevant to nurses' practice of care, contributing to a broad view that favors longitudinal care, such as the relevance of constant contact with 
the users, the effectiveness of the actions enabled by teamwork, the intensified problem-solving as a result of comprehensive care, as well as the benefits of group activities to prevent injuries, promote and recover health.

We observed that many mothers/caregivers would take the child to emergency care units when they found the first symptoms of changes in the health status and they did not monitor the child's growth and development in childcare consultations. This fact can be associated to emergency care networks, which have emergency care units as one of its components $^{(10)}$. Despite this limitation, this study revealed important weaknesses in services and caregiver's dissatisfaction, pointing to the need for improvements in the offered features. As seen in previous studies ${ }^{(10-11)}$, the knowledge of the aspects that involve the Primary Health Care features and its provision for the care of the child are extremely important, since they have the potential to provide subsidies to professionals and managers of the Unified Health System from a perspective of the organization of health services.

In this study, there was a predominance of young mothers ${ }^{(12)}$. As they often have less experience to deal with some of the child's health problems, this can lead to hospitalization. Thus, by recognizing these fragilities, the nurse can guide a more adequate care from prenatal care.

In addition, a higher score for the Degree of affiliation component was found among those who had attended high school, which reinforces that lower schooling and income increase the probability of not having access to primary care ${ }^{(12)}$. There was an opposite situation in the Longitudinality feature, since the participants who had completed elementary education had better scores. This situation may be related to the fact that these users use Primary Health Care more as a guiding source of care than those with a secondary education, since the latter often have a private health plan ${ }^{(13)}$.

Most of the participating families received be- nefit from the Bolsa Família Program, and there was an association of this benefit with the Accessibility component. Similar result was found in a survey ${ }^{(14)}$ that pointed out that enrollment in that Program provides greater frequency of access to health and education systems due to compliance with conditions, in view of the risk of interruption or cancellation of the benefit.

Regarding the most prevalent diagnoses in the study, the cases of pneumonia stood out, making up more than $70.0 \%$ of the sample. The incidence of pneumonia among children under five in developing countries is five times higher than in developed countries $^{(15)}$.

In this study, the children were in the age group of 14-25 months, born at term, which was in line with that found in another study (12 to 24 months) ${ }^{(12)}$. This fact can be considered positive in relation to the context of study, since when children under 12 months of age frequently access hospital services, it means that attention to pregnant women and prenatal care and childcare have serious deficiencies.

Although the mothers of the study reported that they were able to breastfeed up to six months of the baby's life, a fact recognized as a reducing factor of the hospital admission rate ${ }^{(16)}$, there was an association between the Longitudinality feature and the period of Exclusive Breastfeeding from two to four months, coinciding with the period when many women returned to work. This moment may raise in the mothers a greater demand for health services, in an attempt to provide, before returning to work, good health care for their babies.

Regarding the routine follow-up of the children through childcare consultations, we verified that almost half were still attending them. A study carried out in the South region of the country, with the objective of analyzing infant deaths after discharge from the maternity hospital, found that post-discharge follow-up occurred for the majority of the children, predominantly in the public health services. However, this 
reality did not benefit all children, which shows a gap in the assistance ${ }^{(17)}$.

With regard to the team who performed childcare, it was evident that the majority had only the nurse, followed by the joint monitoring with the physician. This finding that can be explained by the role of the nurse before the community as an educator and care professional, who works by sharing knowledge with the population in the face of the various situations encountered in attending this age group.

Therefore, nursing is a field that has an educational dimension for the promotion of self-care and that strives to ensure that health policies and child health care programs are implemented. On the other hand, a study carried out in the city of Maringá, which aimed to know the perceptions of the family members of children about the childcare consultation showed that they had preference for the care performed by the pediatrician $^{(18)}$.

First-contact access refers to the role of Primary Health Care as the "gateway" to the system. When this function is consolidated, there is a reduction in the number of consultations for the same problem, less need for emergency services and fewer hospitalizations, resulting in lower costs and better provision of $\operatorname{care}^{(3,6)}$.

Just like the First-contact access feature, its process components - Use (5.74) - and structure components - Accessibility (3.09) - also did not obtain a satisfactory score. The structure component Degree of affiliation was the only one that obtained a satisfactory score, 7.96. This component refers to the identification and use of a primary health care service as the regular source of care and reflects how much the patient feels as part of the service. Therefore, initially, it is crucial that there is availability in the service and that it meets the needs of the population ${ }^{(3)}$.

Although not included in most of the studies that address the Primary Health Care features, the present study investigated the Degree of affiliation, as it was observed different patterns of health services utilization by the population included in the Family Health Strategy, which also include a portion of registered users who are also affiliated with the private system.

The service use depends on the active attitude of the user, however it is strongly influenced by the characteristics of the services. This implies recognizing that both the physician and the health service used by the child are the first to be sought when there is a need, one of the assumptions of the network organization of the health system, which has primary health care as its integrator and organizer ${ }^{(19)}$.

Accessibility is what facilitates or prevents people from being served ${ }^{(3)}$ and therefore comprises both a geographical component and a socio-organizational component. Regarding this structural component, this study revealed the lowest score (3.09), while the Use component was better evaluated, as previously mentioned. This finding is somewhat paradoxical, since the patient must first recognize the service as accessible and then use it, demonstrating that the availabilities of the services do not meet the expectations of the population $^{(3,20)}$.

Finally, the Longitudinality feature received a poor evaluation among users, reaching a score of 4.39, representing a poor adherence to primary health care principles in this aspect, corroborating with existing scientific evidence ${ }^{(20)}$, which in a similar study obtained a score of 4.93 for this feature. In addition, this feature allows the production of more accurate diagnoses and treatments, reducing unnecessary referrals to specialists and performing more complex procedures $^{(3,14)}$.

Finally, a positive result for the Longitudinality feature can only be possible if the health managers prioritize these services and actions in their scope, insofar as they involve issues such as the adequate provision of primary health care services and mechanisms of establishing the professional in the health unit $^{(14)}$. 


\section{Conclusion}

From the point of view of the mothers/caregivers, primary care services have poorly followed the principles of primary health care, since the scores for the First-contact access and Longitudinality features did not reach the cut of 6.6 , obtaining unsatisfactory scores regarding the presence and the extension of the studied features. This aspect points weaknesses in services and dissatisfaction of caregivers.

\section{Collaborations}

Benevides JL, Gubert FA and Tomé MABG contributed to the conception and design, analysis and interpretation of the data, article writing and critical review of the intellectual content. Vasconcelos PF, Dodt RCM and Pinheiro SRCS contributed to the analysis and interpretation of data, article writing, critical review of intellectual content and final approval of the version to be published.

\section{References}

1. Giovanella L, Almeida PF. Atenção primária integral e sistemas segmentados de saúde na América do Sul. Cad Saúde Pública. 2017; 33(Suppl2):e00118816. doi: https://doi. org/10.1590/0102-311X00118816

2. Mendes EV. Comentários sobre as Redes de Atenção à Saúde no SUS. Divulgação em saúde para debate [Internet]. 2014 [citado 2018 abr 16]. Disponível em: http://www.fcap.adm.br/ wp-content/uploads/2014/07/SeminarioDivulgacao-em-Saude-52-Redes.pdf\#page $=40$

3. Ministério da Saúde (BR). Secretaria de Atenção em Saúde. Departamento de Atenção Básica. Manual do instrumento de avaliação da atenção primária à saúde: Primary Care Assessment Tool Pcatool - Brasil. Brasília: Ministério da Saúde; 2010.
4. World Health Organization. Ending preventable child deaths from pneumonia and diarrhoea by 2025: the integrated Global Action Plan for Pneumonia and Diarrhoea (GAPPD). Geneva: WHO; 2013.

5. Ministério da Saúde (BR). DATASUS - Base de dados do Sistema Único de Saúde. Brasília: Ministério da Saúde; 2013.

6. Ministério da Saúde(BR). Portaria n.221, 17 de abril 2008: publica em forma de anexo a Lista Brasileira de Internações por Condições Sensíveis à Atenção Primária. Brasília: Ministério da Saúde; 2008.

7. Fracolli LA, Gomes MFP, Nabão FRZ, Santos MS, Cappellini VK, Almeida ACC. Primary health care assessment tools: a literature review and metasynthesis. Ciênc Saúde Coletiva. 2014; 19(12):485160.doi:http://dx.doi.org/10.1590/141312320141912.00572014

8. Ferreira JBB, Borges MJG, Santos LL, Forster AC. Internações por condições sensíveis à atenção primária à saúde em uma região de saúde paulista, 2008 a 2010. Epidemiol Serv Saúde. 2014; 23(1):45-56. doi: http://dx.doi.org/10.5123/ S1679-49742014000100005

9. Oliveira MMC, Harzheim E, Riboldi J, Duncan BB. PCATool-ADULTO-BRASIL: uma versão reduzida. Rev Bras Med Fam Comunidade. 2013; 8(29):256-63. doi: http:// dx.doi.org/10.5712/ rbmfc8(29)823

10. Oliveira BRG, Viera CS, Collet N, Lima RAG. Acesso de primeiro contato na atenção primária em saúde para crianças. Rev Rene [Internet]. 2012 [citado 2018 abr. 13]; 13(2):332-42. Disponível em: http://www.periodicos.ufc.br/rene/article/ view/3922/3113

11. Olivira VBFC, Veríssimo MLR. Children's health care assistance according to their families: a comparison between models of Primary Care. Rev Esc Enferm USP. 2015; 49(1):30-6. doi: http://dx.doi. org/10.1590/S0080-623420150000100004

12. Pina JC, Moraes AS, Freitas ICM, Mello DF. Role of Primary Health Care in child hospitalization due to pneumonia: a case-control study. Rev LatinoAm Enfermagem. 2017; 25:e2892. doi: http:// dx.doi.org/10.1590/1518-8345.1731.2892 
13. Jerant A, Fenton JJ, Franks P. Primary care attributes and mortality: a national person-level study. Ann Fam Med. 2012; 10(1):34-41. doi: http://dx.doi.org/10.1370/afm.1314

14. Rocha SF, Soares JL, Reis JGA, Cardoso J. Análise da qualidade de vida dos beneficiários do programa bolsa família na cidade de Porto Velho. Rev Pesq Criação [Internet]. 2011 [citado 2018 abr. 23]; 10(2):59-73. Disponível em: http://www. periodicos.unir.br/index.php/propesq/article/ viewFile/412/454

15. Rudan I, O’Brien KL, Nair H, Liu L, Theodoratou E, Qazi S, et al. Epidemiology and etiology of childhood pneumonia in 2010: estimates of incidence, severe morbidity, mortality, underlying risk factors and causative pathogens for 192 countries. J Glob Health. 2013; 3(1):010401. doi:10.7189/jogh.03.010401

16. Hatisuka MFB, Arruda GO, Fernandes CAM, Marcon SS. Tendency analysis of admission rates for bacterial pneumonia in children and adolescents. Acta Paul Enferm. 2015; 28(4):294-300. doi: http:// dx.doi.org/10.1590/1982-0194201500051
17. Santos EP, Ferrari RAP, Bertolozzi MR, Cardelli AAM, Godoy CB, Genovesi FF. Mortality among children under the age of one: analysis of cases after discharge from maternity. Rev Esc Enferm USP. 2016; 50(3):390-8. doi: http://dx.doi. org/10.1590/S0080-623420160000400003

18. Malaquias TSM, Gaíva MAM, Higarashi IH. Perceptions of the family members of children regarding well-child check-ups in the family healthcare strategy. Rev Gaúcha Enferm. 2015; 36(1):62-8. doi: http://dx.doi.org/10.1590/19831447.2015.01.46907

19. Pina JC, Moraes SA, Furtado MCC, Mello DF. Presence and extent of the primary health care attributes among children hospitalized for pneumonia. Rev Latino-Am Enfermagem. 2015; 23(3):512-9. doi: http://dx.doi. org/10.1590/0104-1169.0502.2582

20. Ferrer APS, Grisi SJFE. Assessment of access to primary health care among children and adolescents hospitalized due to avoidable conditions. Rev Assoc Med Bras. 2016; 62(6):513-23. doi: http://dx.doi.org/10.1590/1806-9282.62.06.513 